\title{
THE WORKER CHARACTERISTIC: THE DECISION TO COMMUTE OR NOT
}

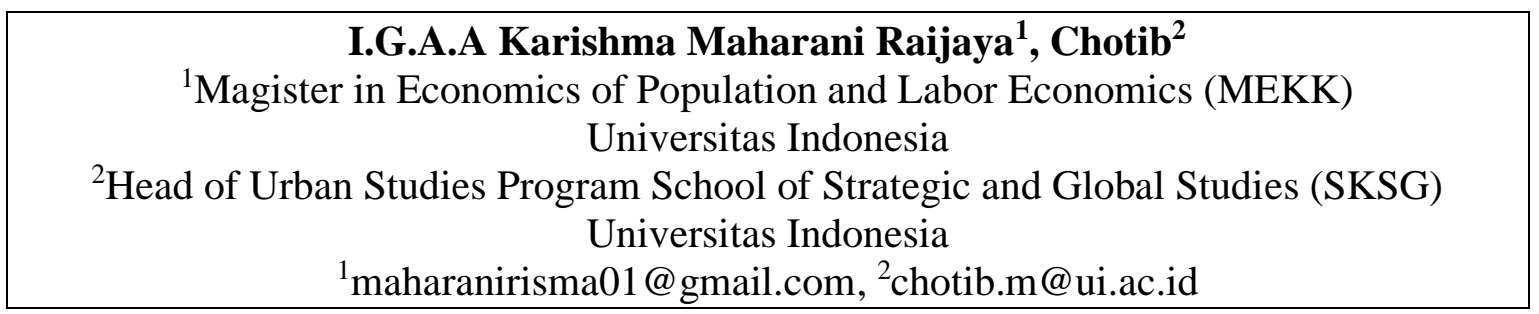

Diterima: Desember 2019; Direvisi Pertama: Januari 2020; Direvisi Kedua: Maret 2020;

Disetujui: April 2020

\begin{abstract}
Commuting is a type of non-permanent mobility where a person works in a different place from his residence. Many problems will arise when the rate of mobility is high, one of them is in Jabodetabek. Jabodetabek certainly have a special pattern in the mobility of its workers or maybe the year change can also change the mobility patterns in Jabodetabek. Therefore, this study will try to analyze and estimate the influence of the social and demographic characteristics of workers in the Jakarta metropolitan area on their decision to commute or not. If more commuter workers are less educated and do not have training certificates, this will have an impact on the burden of the Jabodetabek Metropolitan area. This study uses Sakernas 2018 data, using the Binary Logistic Regression model. The results of this study are the variables of education, gender, and age affect the decision to commute in Jabodetabek.
\end{abstract}

Keywords: binary logistic, commuter, election, Jabodetabek, worker.

Abstraksi. Komuter adalah salah satu jenis mobilitas tidak permanen di mana seseorang bekerja di tempat yang berbeda dari tempat tinggalnya. Banyak masalah yang akan muncul ketika tingkat mobilitas tinggi salah satunya di Jabodetabek. Jabodetabek tentu memiliki pola khusus dalam mobilitas pekerjanya atau mungkin perubahan tahun juga dapat mengubah pola mobilitas di Jabodetabek. Oleh karena itu, penelitian ini akan mencoba menganalisis dan memperkirakan pengaruh karakteristik sosial dan demografi pekerja di wilayah metropolitan Jakarta pada keputusan mereka untuk pulang pergi atau tidak. Jika lebih banyak pekerja komuter kurang berpendidikan dan tidak memiliki sertifikat pelatihan, ini akan berdampak pada beban wilayah Metropolitan Jabodetabek. Penelitian ini menggunakan data Sakernas 2018, menggunakan model Binary Logistic Regression. Hasil dari penelitian ini adalah variabel pendidikan, jenis kelamin, serta usia mempengaruhi keputusan pekerja untuk melakukan komuter di Jabodetabek.

Keywords: binary logistic, Jabodetabek, komuter, pekerja, pilihan.

\section{BACKGROUND}

The increases of population percentage, in urban areas is caused by several factors, firstly, natural birth of the area or excess of births over deaths in urban area, secondly migration of people from rural areas or other cities, thirdly reclassification of rural areas into urban areas (Jones \& Mulyana, 2015). Nurvidya and Ananta (2013) in their journal explained "three Mega-
Demographic Trends in Indonesia", the first trend is the large population, the second trend is the aging population, the third trend is the change in the pattern of population mobility. Indonesia has entered a third trend, that is a shift in the form migration to mobility due to the development of transportation facilities and infrastructure (Nurvidya \& Ananta, 2013). 
Table 1.

Distribution of Stayers, Commuters and Circular Workers of Metropolitan Areas in Indonesia, 2017

\begin{tabular}{|c|c|c|c|c|}
\hline \multirow[t]{2}{*}{ Metropolitan Areas } & \multirow[t]{2}{*}{ Stayers } & \multicolumn{2}{|c|}{ Non permanent Mobility } & \multirow[t]{2}{*}{ Total } \\
\hline & & Commuters & Circulars & \\
\hline Bandung Raya & $85.8 \%$ & $10.9 \%$ & $3.3 \%$ & $100.0 \%$ \\
\hline Banjar Bakula & $89.2 \%$ & $8.9 \%$ & $1.9 \%$ & $100.0 \%$ \\
\hline Gerbangkertosusila & $90.4 \%$ & $8.5 \%$ & $1.1 \%$ & $100.0 \%$ \\
\hline Jabodetabek & $76.4 \%$ & $22.0 \%$ & $1.6 \%$ & $100.0 \%$ \\
\hline Kedungsepur & $87.7 \%$ & $8.5 \%$ & $3.8 \%$ & $100.0 \%$ \\
\hline Mamminasata & $82.3 \%$ & $14.5 \%$ & $3.2 \%$ & $100.0 \%$ \\
\hline Mebidang & $84.2 \%$ & $14.3 \%$ & $1.5 \%$ & $100.0 \%$ \\
\hline Palapa & $95.5 \%$ & $3.4 \%$ & $1.1 \%$ & $100.0 \%$ \\
\hline Patungraya Agung & $95.3 \%$ & $3.0 \%$ & $1.7 \%$ & $100.0 \%$ \\
\hline Sarbagita & $83.9 \%$ & $15.9 \%$ & $0.2 \%$ & $100.0 \%$ \\
\hline Total & $83.0 \%$ & $15.1 \%$ & $1.9 \%$ & $100.0 \%$ \\
\hline
\end{tabular}

Source: Sakernas, 2017. Susiyanto dan Chotib 2018(Susiyanto \& Chotib, 2018).

Table 1 shows the distribution of stayer, commuter, and circular workers in ten metropolitan areas in Indonesia. Most Indonesians live and work in one area. Then the number of distributions in commuter workers, the highest commuter is in Jabodetabek which is 22 percent, then followed by Sarbagita area in Bali Province which is 15.9 percent, and the third is in Mamminasata area which is 14.5 percent. In terms of circular mobility, workers in the Kedungsepur area do a lot of circular mobility (3.8 percent).

The reason of worker mobility is to increase income, get opportunities for better education, and adequate communication and transportation facilities (Nurvidya \& Ananta, 2013). Todaro's theory holds that migration flows occur because of the response to differences in income between rural and urban area. However, the income is not actual income, but expected income (Todaro \& Smith, 2011).

Everett S. Lee stated that the volume of migration in a developing region is in accordance with the level of regional diversity in a particular region. There are three factors that need to be considered in the process of population migration, namely (Mantra, 2000) :

A. Individual Factors

B. Factors in the origin area, such as limitations in land ownership, low wages in rural areas, and lack of job opportunities in rural areas.

C. Factors in the destination area, such as high wage rates, many job opportunities, and various types of jobs.

Migrants in Indonesia mostly live in urban areas. The ratio of migrants living in urban and rural areas is 3: 1 . This shows the flow of population movement to more developed regions. For example, from rural areas to cities or from small cities to big cities (Handiyatmo, 2011).

Obstacles between the area of origin and the destination or referred to as the intermediate factor, namely the factors that become obstacles between the two regions, 
such as means of transportation and the the population commuting with 74 percent distance between rural areas to urban area.

According to the Survei Komuter years old and the number of men compared Jabodetabek 2014, there were 13 percent of to women reached 2:1.

Table 2.

Jabodetabek Commuter Flow Between Regencies/Cities 2014 (Partly)

\begin{tabular}{lcccccccc}
\hline & \multicolumn{7}{c}{ Commuter Destination } \\
\cline { 2 - 9 } Destination & $\begin{array}{c}\text { South } \\
\text { Jakarta }\end{array}$ & $\begin{array}{c}\text { East } \\
\text { Jakarta }\end{array}$ & $\begin{array}{c}\text { Center } \\
\text { Jakarta }\end{array}$ & $\begin{array}{c}\text { West } \\
\text { Jakarta }\end{array}$ & $\begin{array}{c}\text { Bogor } \\
\text { Cities }\end{array}$ & $\begin{array}{c}\text { Bekasi } \\
\text { Cities }\end{array}$ & $\begin{array}{c}\text { Tangerang } \\
\text { Cities }\end{array}$ & Total \\
\hline Bogor Cities & 7034 & 5937 & 8370 & 5345 & - & - & 354 & 72102 \\
\hline $\begin{array}{l}\text { Bogor } \\
\text { Regencies }\end{array}$ & 44665 & 20457 & 48158 & 17414 & 168899 & 16633 & 5194 & 427908 \\
\hline $\begin{array}{l}\text { Bekasi } \\
\text { Cities }\end{array}$ & 71463 & 154175 & 73924 & 23368 & 549 & - & 3378 & 460069 \\
\hline $\begin{array}{l}\text { Bekasi } \\
\text { Regencies }\end{array}$ & 3359 & 63126 & 20431 & 7869 & 335 & 71087 & 373 & 224101 \\
\hline $\begin{array}{l}\text { Tangerang } \\
\text { Cities }\end{array}$ & 55556 & 3724 & 34446 & 89864 & 396 & 554 & - & 283779 \\
\hline $\begin{array}{l}\text { Tangerang } \\
\text { Regencies }\end{array}$ & 7764 & 2505 & 11990 & 25717 & - & - & 106224 & 182455 \\
\hline
\end{tabular}

Table 2.

Continue

\begin{tabular}{lcccccccc}
\hline Destination & \multicolumn{7}{c}{ Commuter Destination } \\
& $\begin{array}{l}\text { South } \\
\text { Jakarta }\end{array}$ & $\begin{array}{l}\text { East } \\
\text { Jakarta }\end{array}$ & $\begin{array}{l}\text { Center } \\
\text { Jakarta }\end{array}$ & $\begin{array}{l}\text { West } \\
\text { Jakarta }\end{array}$ & $\begin{array}{l}\text { Bogor } \\
\text { Cities }\end{array}$ & $\begin{array}{l}\text { Bekasi } \\
\text { Cities }\end{array}$ & $\begin{array}{l}\text { Tangerang } \\
\text { Cities }\end{array}$ & Total \\
\hline Bogor Cities & $9.8 \%$ & $8.2 \%$ & $11.6 \%$ & $7.4 \%$ & - & - & $0.5 \%$ & $100.0 \%$ \\
\hline $\begin{array}{l}\text { Bogor } \\
\text { Regencies }\end{array}$ & $10.4 \%$ & $4.8 \%$ & $11.3 \%$ & $4.1 \%$ & $39.5 \%$ & $3.9 \%$ & $1.2 \%$ & $1000 \%$ \\
\hline $\begin{array}{l}\text { Bekasi } \\
\text { Cities }\end{array}$ & $15.5 \%$ & $33.5 \%$ & $16.1 \%$ & $5.1 \%$ & $0.1 \%$ & - & $0.7 \%$ & $100.0 \%$ \\
$\begin{array}{l}\text { Bekasi } \\
\text { Regencies }\end{array}$ & $15 \%$ & $28.2 \%$ & $9.1 \%$ & $3.5 \%$ & $0.1 \%$ & $31.7 \%$ & $0.2 \%$ & $100.0 \%$ \\
\hline $\begin{array}{l}\text { Tangerang } \\
\text { Cities }\end{array}$ & $19.6 \%$ & $1.3 \%$ & $12.1 \%$ & $31.7 \%$ & $0.1 \%$ & $0.2 \%$ & - & $100.0 \%$ \\
\hline $\begin{array}{l}\text { Tangerang } \\
\text { Regencies }\end{array}$ & $4.3 \%$ & $1.4 \%$ & $6.6 \%$ & $14.1 \%$ & - & - & $58.2 \%$ & $100.0 \%$ \\
\hline
\end{tabular}

Source: Survei Komuter Jabodetabek 2014.

Table 2 shows the pattern of nonpermanent mobility in Jabodetabek area. The workers who live in areas that are still regencies will tend to commute to the nearest city then choose to go to the central city. Worker who live in the city, will tend to commute to the central cities. In the Jabodetabek case, the worker's commuter destination is the closest administrative city from their residence. Then the number of commuters from Bekasi City to East Jakarta can prove the tendency of workers to commute to the nearest administrative city, seen from the percentage is $33.5 \%$. Bekasi City-to East Jakarta are the largest number 
of commuter flow, reached 154175 workers.

Jabodetabek certainly have a special pattern in the mobility of its workers or maybe the year change can also change the mobility patterns in Jabodetabek. Therefore, this study will try to analyze and estimate the influence of the social and demographic characteristics of workers in the Jakarta metropolitan area on their decision to commute or not. If more commuter workers are less educated and do not have training certificates, this will have an impact on the burden of the Jabodetabek Metropolitan area.

\section{LITERATURE REVIEW}

\section{Mobility}

Migration is divided into two categories, firstly circular migration where population movements that cross administrative boundaries at the regency/ city level and routinely go to their destination and return to their place of residence in a weekly or monthly period. Secondly non-permanent migration Commuter mobility, which is the movement of the population routinely going to their destination and returning to their residence in less than 24 hours (Adioetomo \& Samosir, 2015).

Bodenhofer (2016) state that human capital theory has been used to build a simple model of labor mobility as a constituent part of human resource development. The conclusion that can be drawn is that labor mobility goes well, it must be known how the age, education, and other factors affect labor mobility. The most important thing is labor mobility has important implications in the contribution of equitable regional income (Bodenhöfer, 2016).
High population growth and dominant proportion of young population, education and skills, employment opportunities, income differences, transportation and communication facilities, political freedom and human rights, and urbanization are the main causes of population migration (Samuel \& George, 2002).

\section{Empirical Study}

On the scale of travel, traveling to work considers several factors including content, travel length, complexity, and distance in the mobility of men and women involved in daily mobility (Cresswell, Dorow, \& Roseman, 2016). The social production and reproduction require special attention in the factors of destination, distance, transportation mode used, travel time, and other structural factors that distinguish mobility of both men and women.

(Trendle \& Siu, 2005) examined the pattern of commuting in the city of Sunhine Coast at different levels of education. The results are the worker concern to high income, not to the condition between the destination and the origin area. The high educated workers do not care about the conditions on the origin area.

The differences in commuter patterns by sex in the Tokyo metropolitan area. The results obtained are differences in outcomes between generations where male workers tend to have a longer commuter time compared to women. For married women, they tend to quit their jobs and choose to become a housewife (Kawase, 2004).

Age, sex, type of work, and home ownership status had a relationship with work location. Commuter time has a relation with age and type of work, whereas commuter distance has a relationship with home ownership status, while gender does 
not have a significant effect on time or commuter distance (Punpuing, 1993).

\section{ANALYSIS METHOD}

This study used data from SAKERNAS (Survei Angkatan Kerja Nasional or National Labor Force Survey) 2018. Sakernas is a survey conducted by the Badan Pusat Statistik specifically designed to collect data that can describe the general state of employment between periods of enumeration (BPS, 2018).

The location of this research in the Jakarta metropolitan area and the unit of analysis in this study is focused on residents who work in the Jabodetabek area, namely Jakarta, Bogor, Depok, Tangerang, Bekasi, which are included in the working age population, those aged is 15 years and over who commute to work or not.

The analytical method used in this study is a binary logistic regression model. The model is used because the dependent variable (Y) grouped into two categories, $0=$ if the respondent not a commuter worker, $1=$ if the respondent is commuter worker (Hasyasya \& setiawan, 2012).

$\ln \left(\frac{p}{1-p}\right)=\beta_{10}+\beta_{11}$ educ $+\beta_{12}$ sex $+\beta_{13}$ age $+\beta_{14}$ mar $_{\text {stat }}+\beta_{15}$ wage $+\beta_{16}$ train $+\mu_{i} \ldots .$.

Information :

$\begin{array}{ll}\text { Wage } & =\text { Income per month; } \\ & \text { Numeric } \\ \text { Sex } & =0, \text { male; } 1 \text {, female } \\ \text { Educ } & =0, \text { if the education }>\text { Senior }\end{array}$

High School; 1, if the education <Junior High School.

Age $\quad=$ Age of worker; Numeric.

mar_stat $\quad=1$, if the marital status is single; 2 if the marital status is married; 3 if the marital status is divorced/widowed.

Train $=0$, if have received training/courses and obtained a certificate; 1 , if do not have received training/courses and obtained a certificate.

\section{RESULTS AND DISCUSSION}

\section{Descriptive Analysis}

Jakarta is the capital state of Indonesia and the largest city in Indonesia. The development of Jakarta has had an effect on areas around Jakarta, namely Bogor, Depok, Tangerang and Bekasi. Because of this development Jabodetabek emerged as one of the metropolitan areas in Indonesia. This has led to urbanization, migration and population mobility to work in the region because they hope to get a higher income. The most obvious impact is that if commuter workers have low education (education as one of the assumptions that the worker does have the appropriate skills), this will put a special burden on regulation in the Jabodetabek area. In this descriptive analysis we will further deepen the discussion about how the social and demographic characteristics of commuter workers in the Jabodetabek area. 
Table 3.

Choice of Mobility and Education

\begin{tabular}{cccccc}
\hline $\begin{array}{c}\text { Frequency of } \\
\text { Mobility }\end{array}$ & \multicolumn{5}{c}{ Education } \\
\cline { 2 - 6 } & $\begin{array}{c}\text { Primary } \\
\text { school }\end{array}$ & $\begin{array}{c}\text { Junior } \\
\text { high } \\
\text { school }\end{array}$ & $\begin{array}{c}\text { Senior high } \\
\text { school }\end{array}$ & $\begin{array}{c}\text { > Senior } \\
\text { high } \\
\text { school }\end{array}$ & Total \\
\hline $\begin{array}{c}\text { Not a } \\
\text { commuter } \\
\text { worker }\end{array}$ & 3461 & 3119 & 4410 & 1361 & 12351 \\
\cline { 2 - 6 } & $28.02 \%$ & $25.25 \%$ & $35.71 \%$ & $11.02 \%$ & $100 \%$ \\
\hline $\begin{array}{c}\text { A commuter } \\
\text { worker }\end{array}$ & 2106 & 1397 & 3950 & 2264 & 9717 \\
\hline Total & $21.67 \%$ & $14.38 \%$ & $40.65 \%$ & $23.30 \%$ & $100 \%$ \\
\hline & 5567 & 4516 & 8360 & 3625 & 22068 \\
\hline
\end{tabular}

Source: Sakernas, raw data 2018, processed.

Table 3. show the choice of mobility decision based on worker education. high school graduate workers tend to choose to commute than others because more higher the level of education, the work productivity will also increase. This has an impact on increasing income (Warsida, Adioetomo, \& Pardede, 2013).

Table 3 shows that $337.88 \%$ of the total workers, both commuting or not, were dominated by high school and vocational high school education level. As many as $40.65 \%$ of workers who do commuting mobility are dominated by senior high school and vocational high school level. The results of this study were that most of the workers in the Jabodetabek Area only had high school and vocational high school level education and below. This is will have an impact on increasing the supply of high school and vocational high school workforce in Jabodetabek and will force these workers to find work in different regions. Due to the small amount of income received, and public transportation in the Jabodetabek area has many choices, this has led to an increase in commuter workers at the high school and vocational school levels. This is will have an impact on the burden that will be borne by Jabodetabek metropolitan area will be even harder to increase human capital based on education.

Table 4.

Choice of Mobility and Sex

\begin{tabular}{cccc}
\hline Frequency of Mobility & Male & Female & $\begin{array}{c}\text { Total } \\
\text { Observations }\end{array}$ \\
\cline { 2 - 4 } & 4351 & 8000 & 12351 \\
\hline $\begin{array}{c}\text { Not a commuter } \\
\text { worker }\end{array}$ & $35.23 \%$ & $64.77 \%$ & $100 \%$ \\
\hline A commuter worker & 6578 & 3139 & 9717 \\
\cline { 2 - 4 } & $67.70 \%$ & $32.30 \%$ & $100 \%$ \\
\hline Total & 10929 & 11139 & 22068 \\
& $49.52 \%$ & $50.48 \%$ & $100 \%$ \\
\hline
\end{tabular}

Source: Sakernas, raw data 2018, processed. 
Research conducted by Suryadi (2014) stated that the majority of commuter workers in Jabodetabek are male, and reached $66.02 \%$ (Suryadi, 2014).

Table 4 shows the choice of commute or not based on the sex of the worker.
Observations show that male workers commute more than female. $67.70 \%$ of men do the commuting to work, and only $32.30 \%$ of women.

Table 5.

Choice of Mobility and Age Group

\begin{tabular}{cccc}
\hline Age & Not a commuter worker & A commuter worker & Total Observation \\
\hline $\mathbf{1 5 - 1 9}$ & $87.76 \%$ & $12.24 \%$ & 2638 \\
\hline $\mathbf{2 0 - 2 4}$ & $50.95 \%$ & $49.05 \%$ & 2369 \\
\hline $\mathbf{2 5 - 2 9}$ & $40.59 \%$ & $59.41 \%$ & 1929 \\
\hline $\mathbf{3 0 - 3 4}$ & $45.02 \%$ & $54.98 \%$ & 1897 \\
\hline $\mathbf{3 5 - 3 9}$ & $46.00 \%$ & $54.00 \%$ & 2311 \\
\hline $\mathbf{4 0 - 4 4}$ & $44.45 \%$ & $55.55 \%$ & 2459 \\
\hline $\mathbf{4 5 - 4 9}$ & $46.87 \%$ & $53.13 \%$ & 2379 \\
\hline $\mathbf{5 0 - 5 4}$ & $48.55 \%$ & $51.45 \%$ & 1961 \\
\hline $\mathbf{5 5 - 5 9}$ & $59.86 \%$ & $40.14 \%$ & 1572 \\
\hline $\mathbf{6 0 - 6 4}$ & $74.01 \%$ & $25.99 \%$ & 1116 \\
\hline $\mathbf{6 5 - 6 9}$ & $78.88 \%$ & $21.12 \%$ & 729 \\
\hline $\mathbf{7 0 - 7 4}$ & $83.01 \%$ & $16.99 \%$ & 365 \\
\hline $\mathbf{7 5 +}$ & $94.46 \%$ & $5.54 \%$ & 343 \\
\hline Total & $\mathbf{5 5 . 9 7} \%$ & $\mathbf{4 4 . 0 3 \%} \%$ & $\mathbf{2 2 0 6 8}$ \\
\hline
\end{tabular}

Source: Sakernas, raw data 2018, processed.

Commuter worker research in the had to change trains two to three times. Due Semarang city state that age greatly to long travel time, workers should have influences a person's decision to commute. good physical condition (Warsida et al., In general, older workers usually intend to 2013). stay or refuse to commute. Mostly, the age of commuter workers is in the productive age group or young age. At the age of 50 years or more, a person relies more on his children, retirees, investment or savings, and so on (Hasyasya \& setiawan, 2012).

Table 5 shows the choice to commute or not by the worker based on age group. In general, the older workers will choose not to do commuting, because it will require a lot of energy and physical strength to travel long distances to their destination areas. Like in Jakarta, for example, commuters

Table 5 shows that the older the workers are, the lesser the commuting rate is. The highest number of commuter workers is in the age group 25-29 years, reaching $59.41 \%$. Then there is a decrease in trends in the next age group.

Figure 1 shows the choice to commute or not to commute by the worker based on single age. The pattern looks like an inverted $U$ pattern. Figure 1 shows that young age tends to commute than other ages. Most of the workers who did the commuting were at the specific age, which 
is 26-year-old workers, reaching $63.32 \%$. physical abilities and capable of At this age, workers generally have good commuting.

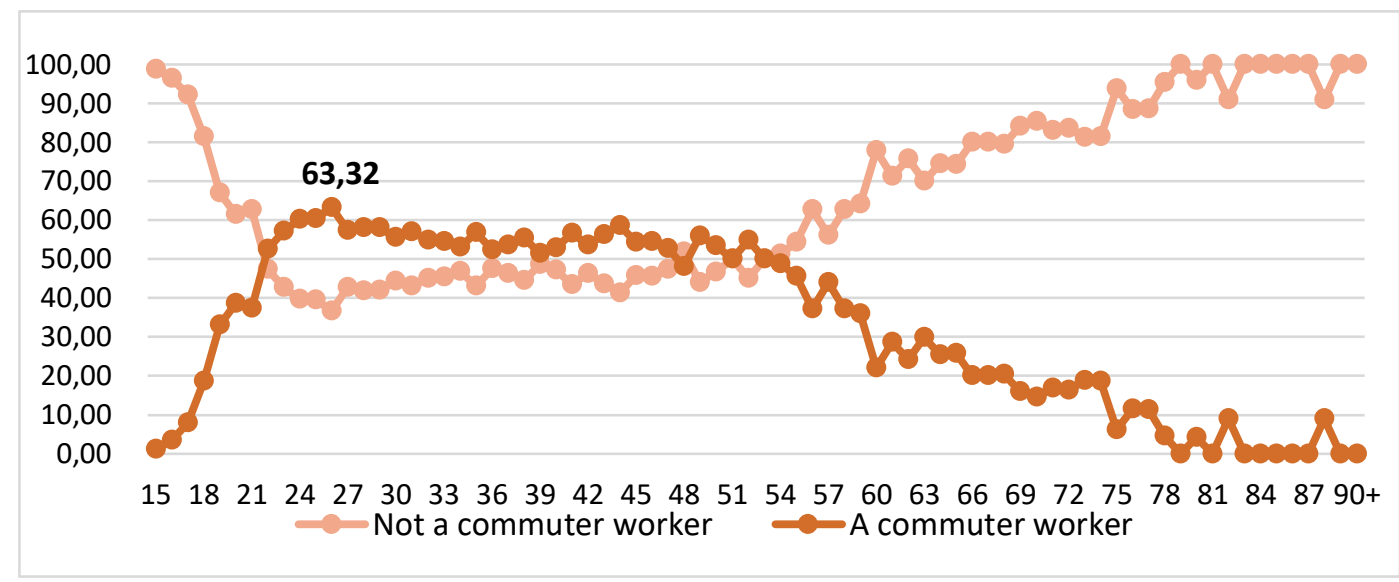

Figure 1. Choice of Mobility based on Age

Source: Sakernas, raw data, processed 2018.

Table 6.

Choice of Mobility and Marital Status

\begin{tabular}{cccc}
\hline Marital Status & $\begin{array}{c}\text { Not a commuter } \\
\text { worker }\end{array}$ & $\begin{array}{c}\text { A commuter } \\
\text { worker }\end{array}$ & $\begin{array}{c}\text { Observations } \\
\mathbf{( 1 0 0 \% )}\end{array}$ \\
\hline Single & 3831 & 2551 & 6382 \\
\cline { 2 - 4 } & $60.03 \%$ & $39.97 \%$ & $100 \%$ \\
\hline Married & 7166 & 6584 & 13750 \\
\cline { 2 - 4 } & $52.12 \%$ & $47.88 \%$ & $100 \%$ \\
\hline Divorced/Widowed & 1354 & 582 & 1936 \\
\cline { 2 - 4 } & $69.94 \%$ & $30.06 \%$ & $100 \%$ \\
\hline Total & 12351 & 9717 & 22068 \\
& $55.97 \%$ & $44.03 \%$ & $100 \%$ \\
\hline
\end{tabular}

Source: Sakernas, raw data, processed 2018.

Table 6 shows the mobility of worker and marital status. Marital status is divided into three categories namely single, married, and divorced/widowed workers. Based on choice of commuting or not, workers who are single tend not to commute for work. Then for married workers prefer to commuting. In general, married workers tend to commute for going to work compared to single or divorced/widowed workers (Warsida et al., 2013).
A divorced person doesn't consider the family left behind because they don't have a husband or wife. Therefore, a divorced person would prefer to live close to the work place. Although there are considerations of already having children, someone who has divorced usually entrusts his child to his parents or siblings.

Someone who is married, usually already has children and a small family. Someone with many dependents, such as dependents on children will tend to choose become a commuter worker. This is 
because someone who is married will think more about their children's school, take care of children in a new school, husband or wife's work, so to move house close to where work will feel more difficult.

Table 7.

Choice of Mobility and Have Received Training/Courses and Obtained a Certificate

\begin{tabular}{cccc}
\hline Train & $\begin{array}{c}\text { Not a commuter } \\
\text { worker }\end{array}$ & $\begin{array}{c}\text { A commuter } \\
\text { worker }\end{array}$ & $\begin{array}{c}\text { Observations } \\
\mathbf{( 1 0 0 \% )}\end{array}$ \\
\hline Have & 838 & 1034 & 1872 \\
\cline { 2 - 4 } Do not have & $44.76 \%$ & $55.24 \%$ & $100 \%$ \\
\cline { 2 - 4 } & 11513 & 8683 & 20196 \\
\hline Total & $57.01 \%$ & $42.99 \%$ & $100 \%$ \\
\cline { 2 - 4 } & 12351 & 9717 & 22068 \\
\hline & $55.97 \%$ & $44.03 \%$ & $100 \%$ \\
\hline
\end{tabular}

Source: Sakernas, raw data, processed 2018.

Table 7 shows that many commuter workers received training/courses and obtained certificates (55.24\%). Only 1872 workers have received training/courses and received certificates of 22068 workers.

In general, training/courses can help workers to improve their skills. Training/courses also make the selling power of workers higher and have an impact on increasing productivity and increasing income to increase family welfare and financial (Ranita \& Siddin, 2019). Table 3 also shows that workers in the Jabodetabek area are dominated by workers with high school and vocational education levels, and have never attended training/courses to improve their skills. This can be a challenge in improving worker education and worker skills in order to have competitiveness.

\section{Inferential Analysis}

Inferential analysis is intended to estimate the population through sample characteristics through a binary logistic model using STATA 14.0. Because the dependent variable consists of two choices, commuter worker or not, the regression analysis used is Binary Logistic Regression. In this regression, code $0=$ if the respondent not a commuter worker, $1=$ if the respondent is commuter worker. The variables used in this study are education, sex, age, marital status, wage, and Training/Courses, affect the commuting or not of the worker. In the inferential analysis also stated the hypothesis that supports this research. The hypothesis used is based on theory and previous research.

The significance level used is $* \mathrm{p}<0.05$, $* * \mathrm{p}<0.01, \quad * * * \mathrm{p}<0.001$, based on this, researchers can determine the critical area of rejection of $\mathrm{H}_{0}$ or accepted $\mathrm{H}_{1}$. Rejecting $\mathrm{H}_{0}$ means that parameter $\mathrm{B}$ is not equal to zero which means that there is a significant influence of an independent variable on the dependent variable. In addition to the parameter B, also displayed OR (Odd Ratio) which shows how many times the risk of a free variable category is likely to be pi compared to the reference variable category. in binary logistic regression, OR is used to interpret the relation between independent and dependent variables. 
Table 8 shows the results of the Binary logistic Regression in the Choice of Mobility. There are three insignificant variables, namely marital status, wage, and training, and three significant variables which are junior high school significant with $\mathrm{p}<0.05$, senior high school and $>$ senior high school significant with $p<0.001$. Sex (female) significant with $\mathrm{p}<0.001$. Age significant with $\mathrm{p}<0.05$.

Variable education, in the junior high school level, workers tends to be 1.37 times more likely to commute. In the senior high school level, workers tend to be 4.51 times more likely to commute and > senior high school level, workers tend to be 6.15 times more likely to commute. The sex variable, the coefficient result is negative, this is shows that female worker tends to be 0.54 times more not likely to commute. This result is related to Table 4 , where the most commuter workers are male workers. For the age variable coefficient result is negative. this means that the older the workers are, the less likely they are to commute. This result is related to Table 5 and Figure 1.

Table 8.

Binary logistic Regression in the Choice of Mobility

\begin{tabular}{lccc}
\hline \multicolumn{1}{c}{ Mobility } & Coef. & Odds Ratio & Sig. \\
\hline Educ & & & \\
\hline Junior high school & 0.04135 & 1.36834 & $0.022^{*}$ \\
\hline Senior high school & 0.10709 & 4.51199 & $0.000^{* * *}$ \\
\hline \multicolumn{1}{r}{ Senior high school } & 0.11820 & 6.14705 & $0.000^{* * *}$ \\
\hline sex (Female) & -0.03477 & 0.53980 & $0.000^{* * *}$ \\
\hline age & -0.00351 & 0.94582 & $0.035^{*}$ \\
\hline mar_stat & & & \\
\hline \multicolumn{1}{c}{ Married } & 0.00111 & 1.01230 & 0.935 \\
\hline Divorced/Widowed & -0.03603 & 0.75282 & 0.198 \\
\hline Do not have train/courses & 0.00510 & 1.05220 & 0.522 \\
\hline cons & 0.01020 & 1.33942 & 0.114 \\
\hline
\end{tabular}

Source: Sakernas, raw data, processed by author 2018 .

Significant with $* \mathrm{p}<0.05,{ }^{*} \mathrm{p}<0.01, * * * \mathrm{p}<0.001$

\section{CONCLUSION}

This article reviews the choice of worker mobility, as a commuting or not. The results show that a person's social characteristics will affect the choice of mobility decision. There are still many people who commute to work, namely young workers, with high school and vocational education, have training certificates/courses, and married.

All variables affect the choice mobility. All variables used, there are three variables that affect the commuting worker which are education, gender, and age. In general, workers who commute will use their income in the area of residence. This is 
expected to increase the purchasing power of the area and have an impact on equity.

Previous research conducted by Warsida, Adioetomo, and Pardede 2013, states that men are more likely to commute than women. Women's mobility tends to be more limited by space and distance because of the role of women in managing the household, while men have the main role to work so they tend to have higher levels of mobility (Suryadi, 2014). The age variable has a U-inverse relationship with commuting opportunities (Warsida et al., 2013).

Based on the variable of wage and education level show a positive effect on commuting (Hasyasya \& setiawan, 2012).
There are differences in research results obtained that the level of education does not have a positive relationship with commuting. Descriptive results in table 3 show that workers with the highest level of education are the most dominant compared to workers with >high school education.

Hasyasya \& setiawan, 2012 state that educational variables do not significantly influence the decision of workers to commute. It is suspected that there are many industrial areas in the Semarang city require a lot of workers, this makes workers who have low education also want to commute. In contrast to this study, the educational variable has a significant effect on the decisions of workers commuting.

\section{REFERENCE}

Adioetomo, S. M., \& Samosir, O. B. (2015). Dasar-Dasar Demografi (4th ed.). Jakarta: Salemba Empat.

Bodenhöfer, H.-J. (2016). The Mobility of Labor and The Theory of Human Capital. The Journal of Human Resources, 2(4), 431-448. https://doi.org/10.4135/9781412969024.n17

BPS. (2018). Kuisioner SAKERNAS.

Cresswell, T., Dorow, S., \& Roseman, S. (2016). Putting mobility theory to work: Conceptualizing employment-related geographical mobility. Environment and Planning A, 48(9), 1787-1803. https://doi.org/10.1177/0308518X16649184

Handiyatmo, D. (2011). Migrasi Internal Penduduk Indonesia Hasil Sensus Penduduk 2010. In Badan Pusat Statistik. Jakarta: Badan Pusat Statistik.

Hasyasya, N., \& setiawan, A. H. (2012). Analisis Faktor-Faktor Yang Mempengaruhi Keputusan Tenaga kerja menjadi Commuter dan Tidak Menjadi Commuter ke Kota Semarang (Kasus Kabupaten Kendal). Diponegoro Journal Of Economics, 1(1), 1-10.

Jones, G., \& Mulyana, W. (2015). Urbanization in Indonesia (4th ed.). Jakarta: United Nations Population Fund.

Kawase, M. (2004). Changing gender differences in commuting in the Tokyo metropolitan suburbs. GeoJournal, 61(3), 247-253.

Mantra, I. B. (2000). Demografi Umum (1st ed.). Yogyakarta: Pustaka Pelajar.

Nurvidya, E., \& Ananta, A. (2013). Mega Demographic Trends. Sosial Development Issues, 35(3). 
Punpuing, S. (1993). Correlates of commuting patterns: a case-study of Bangkok, Thailand. Urban Studies, 30(3), 527-546. https://doi.org/10.1080/00420989320080531

Ranita, S. V., \& Siddin, F. N. (2019). a Literature Review: Women Worker Commuting Productivity Informal Sector. International Journal of Modern Trends in Social Sciences, (2011), 23-31. https://doi.org/10.35631/ijmtss.28003

Samuel, J., \& George, S. (2002). Globalization, Migration and Development. Canadian Studies in Population, 29(1), 31. https://doi.org/10.25336/p6jw2p

Suryadi. (2014). Profil dan Positioning Komuter di Jabodetabek Menggunakan Analisis Korespondensi. Warta Penelitian Perhubungan, 26(6), 299-310.

Susiyanto, G. A., \& Chotib. (2018). Who Decides to Stay, Who Decides to Move: The Pattern And Characteristics Of Stayers And Movers In Indonesian Metropolitan Areas (National Labour Force Survey Data Analysis Of 2017). https://doi.org/10.1227/01.NEU.0000327693.86093.3F

Todaro, M., \& Smith, S. C. (2011). Economic Development (11th ed.). Addison-Wesley, New York, NY. In Addison-Wesley.

Trendle, B., \& Siu, J. (2005). Commuting Patterns of Sunshine Coast Residents and the Impact of Education. Training, 13(37), 17.

Warsida, R. Y., Adioetomo, S. M., \& Pardede, E. L. (2013). Pengaruh Variabel SosioDemografis terhadap Mobilitas Ulang-Alik di Jabodetabek The Effect of SocioDemographic Variables on Commuting in Jabodetabek Pendahuluan. Jurnal Ekonomi Dan Pembangunan Indonesia, 13(2), 159-176. 